Мороз Людмила, кандидат філологічних наук, доцент, завідувач кафедри іноземних мов Рівненський державний гуманітарний університет

\title{
ПРОБЛЕМИ ТЕРМІНОЛОГІЧНОГО ОЗНАЧЕННЯ ТА ТЕОРЕТИЧНОГО ОСМИСЛЕННЯ РОЛЬОВОЇ ЛІРИКИ
}

У статті досліджено художній феномен рольової лірики. Проаналізовано проблематику теоретичних пошуків літературознавців у дослідженні специфіки суб'єктної організачії лірики. Охарактеризовано спектр суб'єктів поетичного мовлення. Розглянуто питання, пов'язані із прийомами композиційного та мовленнєвого оформлення поетичного рольового тексту. Окреслено кониептуально-змістовні його ракурси, які виявляють себе на рівні вираження ідейно-тематичних конщептів твору.

Ключові слова: рольова лірика, персонажна лірика, автопсихологічна лірика, рольовий герой, ліричний герой. 


\section{Moroz L. Problems of terminological definition and theoretical comprehension of role}

lyrics.

The article investigates the artistic phenomenon of role lyrics. It also analyzes the problems of theoretical searches of literary critics in the study of lyrics subject organization specifics. The spectrum of poetic speech subjects is characterized. The specifics of artistic expression in the role poetry texts are outlined. The article also makes emphasis on conceptually meaningful perspectives which reveal themselves at the level of ideological and thematic concepts expression.

From the second half of the twentieth century the special attention of researchers attracts the problem of lyrics subject organization and, accordingly, the forms of its artistic typology. Actuality of this problem has come about in the poetry of the nineteenth and especially the twentieth century concerning complication of the forms of author's consciousness expression as well as with the assertion in its array of so-called role-playing lyrics opposed to the autopsychological lyrics. The purpose of scientific investigation is to study the issues of role lyrics poetry in the system of subjective forms of expression of author's poetic consciousness. One of the first scholars in philology who initiated research on role lyrics was the famous literary critic B. Korman, who noticed and theoretically substantiated its artistic phenomenon. The study of one or the other issues of role-playing lyrics poetry was also conducted by A. Borovsky, I. Vasiliev, I. Kargashin, S. Artyomina, O. Garkavi, V. Skobelev, L. Ginzburg and others. At the same time, many issues of poetry in role-playing lyrics still remain underdeveloped, in particular, the techniques of its artistic organization and issues. It is stated in the article that in general the subject organization of the lyrical work is considered to be a system of artistic forms in which the author's consciousness can reveal itself in poetic text.

It is determined that one of the main theoretical problems in this literary sphere is the problem of the impossibility of direct identification of the subject of speech from the person of whom the narrative is organized in a lyrical work with the author himself. It is noted that the voice of the author and the voice of the subject from the person who initiated the speech in the text of the poetic work can be combined by the acquisition of various forms of artistic synthesis or, as the literary critics put it, "polyphony".

So, as can be deduced, the generally accepted concept of role lyrics in modern literary criticism has not yet been developed, therefore, its artistic phenomenon has not been identified in the conceptual scope which would clearly outline its artistic essence determining semantic features. There is no unified literary terminology on the designation of this artistic phenomenon. In our opinion, from the total number of terms proposed by modern literary studies, the most successful is the term "role lyrics" which most accurately reflects the semantic essence of its phenomenon as a lyric in which the author speaks not from himself but from the person of the imaginary subject of speech i.e. the role which he performs in this case (as, in fact, the fictional subject of his speech performs, at least fictitiously, the role of the poetic text author). The closest and often used terminological analogue of role lyrics, namely, the character's lyric, in our opinion, does not quite clearly reflect the fundamental semantic features of its artistic phenomenon. First of all, the character depicted in the poetic work does not always act as the subject of speech (and only the object of the author's representation). In our research lyric poetry will include poetry texts built in the form of a holistic speech statement organized from a person who is distanced from the author and can not be identified with him considering biographical, social, historical or gender status of the subject of speech declared in his work as well as a range of moral, ethical, ideological, aesthetic, existential values represented by him.

The research of the part role lyrics plays in poetry in general testifies that the problem of establishing clear conceptual boundaries between the lines of the linguistic work defined in typological models is not likely to be resolved at the present time. The article underlines the most urgent issues of debate which need further study and includes problems of artistic varieties definition as well as the classification of characters types in role lyrics.

Key words: lyric poetry, subjective organization of lyrics, subject of poetic speech, author, author's voice, lyrical hero, hero of role lyrics. 
Постановка проблеми. 3 другої половини XX ст. особливу увагу дослідників привертає проблема суб’єктної організації лірики і, відповідно, форм їі художньої типологізації. Актуальності ця проблема набула у зв’язку як iз загальним ускладненням в поезії XIX i особливо XX ст. форм вираження авторської свідомості, так і з утвердженням у іiі масиві так званої рольової лірики, протиставленої ліриці автопсихологічній.

Аналіз останніх досліджень і публікацій. Одним 3 перших вченихфілологів, що ініціював дослідження рольової лірики, був відомий літературознавець Б. Корман, який зауважив i теоретично обгрунтував $\dddot{1}$ художній феномен. Дослідженю тих або тих питань поетики рольової лірики присвячено також літературознавчі розвідки А. Боровської, I. Васильєва, I. Каргашина, С. Артьоміної, О. Гаркаві, В. Скобєлєва, Л. Гінзбург та ін. Водночас, чимало питань поетики рольової лірики усе ще залишаються недостатньо дослідженими, зокрема, прийоми іiі художньої організації та проблематики.

Метою нашої наукової розвідки є дослідження проблем термінологічного означення та теоретичного осмислення рольової лірики.

Виклад основного матеріалу дослідження. Термін «рольова лірика» достатньо новий і навіть ще не зовсім узвичаєний у літературознавчій практиці. Наприклад, автор відомого підручника «Теорія літератури» В. Халізєв, визначаючи рольову лірику як лірику, «в якій виражаються переживання особи, щзо помітно відрізняється від автора ... (на відміну від автопсихологічної)», вдається й до суб'єктивних коментарів, у яких намагається спростувати iї художній статус: «але магістральною лінією ліричної творчості $\epsilon$ поезія не рольова, а автопсихологічна: вірші, щ⿻о представляють собою акт прямого самовираження поета. Для читача цінною є людська дійсність ліричного переживання, пряма присутність у вірші, за словами В. Ф. Ходасевича, “живої душі поета”: «Особистість автора, не прихована стилізачією, стає нам ближчою»; гідність поета полягає «в тому, 
щуо він пище, підпорядковуючись потребі висловити власні переживання» $[1$, c. 352$]$.

Безперечно, не підлягає сумніву той факт, що автопсихологічна лірика була i залишається основною формою вираження авторської свідомості, водночас представництво у загальному масиві поетичних творів рольової лірики також $є$ достатньо суттєвим. Очевидною й $є$ тенденція (особливо відчутна в поезії XX ст.) до розширення як кола митців, що звертаються до рольових форм ліричного самовираження, так i жанро-стильового i тематичного спектру рольових текстів поезії. Наразі це свідчить про те, що поряд із автопсихологічною, рольова лірика відіграє важливу роль у художніх пошуках форм вираження ліричного «я» поетами - представниками різних літературних напрямів та шкіл. Феномен рольової лірики, на відміну, звичайно до певної міри, від лірики автопсихологічної, $\epsilon$ достатньо складним і у належному обсязі ще не опрацьованим сучасним літературознавтвом, про що, зокрема, свідчать й численні розбіжності в теоретичних рецепціях, у яких дослідники намагаються визначити іiі основоположні семантичні ознаки. «Складнішими є справи з рольовою (ї̈ щее називають персонажною) лірикою. Констатує російська дослідниця О. Орлова. - У ній всю поезію написано від особи персонажа («іншого» по відношенню до автора). Стосунки автора $i$ персонажа можуть бути різними. У вірші Некрасова «Моральна людина» сатиричний персонаж не тільки категорично далекий від автора, але й служить предметом викриття, сатиричного заперечення. $A$, скажімо, ассірійський цуар Ассаргадон «оживає» $i$ розповідає сам про себе у віриі В. Брюсова «Ассаргадон». Але при цуьому зрозуміло, щуо нам не спаде на гадку ототожнювати самого поета з героєм його рольової лірики» [2, с. 29].

До спроби теоретичної деталізації статусу художнього вияву рольового «я» у поезії звертається I. Васильєв коментуючи його так: «Рольова лірика, як лірика чужого «Я» передбачає емпатію - здатність сприймати з усією повнотою проблематику життєвої ситуації інщої людини, вміння поставити себе на ї̈ місие і відчувати ї̈ почуття та емощиї. / ... / У рольовій ліриці 
посередництвом образного переадресування відбувається переміщення до різних аспектів реальності і різноманітних життєвих контекстів: соџіальнопсихогічних з урахуванням особистісно-ситуативних, групових, професійних, вікових та інших факторів» [3, с. 58-59, 61].

Важливу ознаку рольової лірики дослідники справедливо вбачають у специфіці іï суб’єктної організації, яка передбачає певну форму художньої взаємодії двох типів суб'єктного вияву авторської свідомості - власне автора і його героя, від особи якого організовано розповідь у творі: «Беззаперечною $\epsilon$ актуальність питання про форми вираження авторської свідомості в текстах так званої «рольової» поезї («рольової» лірики). У сучасному літературознавстві «рольову» лірику визначено як лірику «неавторського» чужого я. Іншими словами, у “рольовому” вірші “прямо” - безпосередньо виражено свідомість не автора, але персонажа: суб'єкта свідомості одночасно виявлено об'єктом авторського свідомості» [4, с. 134].

Двосуб'єктність текстів рольової лірики зауважує й Є. Андрієнко: «Серед текстів з експлічитно вираженим відправником досить численними є вірші рольовим «я»-суб'єкта. Основна особливість рольових віршів полягає у тому, що вони двосуб'єктні. Герой “рольового” вірша виступає у двох функиіях: суб'єкт свідомості і об'єкт іншої, більш високої свідомості. Він наділений різко характерною мовною манерою, своєрідність якої вирізняється на тлі літературної норми. Ця манера дозволяє співвіднести образ “я” з певним соиіально-побутовим та культурно-історичним середовищем» [5, с. 28].

Інша дослідниця - О. Ревзіна намагаєтьться пояснити феномен двосуб'єктності рольової лірики поняттям літературної маски, яку, на ії думку, надягає на себе автор відповідного твору: «рольовий суб'єкт представлений тоді, коли реальний «я»-суб’єкта, зберігаючи право авторського голосу, приймає на себе певну роль або маску - фольклорну, романтичну, грамотіякнижника і т.n.» [6, с. 112].

Якщо стосовно основних семантичних параметрів рольової лірики, таких як наявність у іï структурі нетотожного авторській свідомості ліричного 
«голосу» i специфічного дворівневого типу иï суб’єктної організації серед дослідників панує одностайність, то теоретичний статус самого рольового героя оцінюється ними по-різному. Наприклад, С. Артемова акцентує на тому, що рольовий герой - це специфічна суб'єктна форма вияву авторської свідомості, яка є відмінною від іншого типу, а саме - ліричного героя [7, с. 213-214].

Інші дослідники, навпаки, схильні вбачати риси певної тотожності між власне рольовим і ліричним героєм, як двома суміжними формами вияву авторського ліричного «я». Зокрема, Т. Тіліпіна не лише вважає рольового героя двійником героя ліричного, а й суттєво звужує тематичне коло художніх образів, які потенційно можуть претендувати на подібний теоретичний статус: «Для нас рольова лірика передбачає твір з таким героєм, який, перебуваючи емпірично віддаленим від життя автора, має впізнавані читачем риси естетично значущухх персонажів літератури $і$ фольклору. Вони допомагають поетові виявити власне «я». Перебуваючи у статусі двійника ліричного героя, рольовий герой виконує особливу функиію, завериуючи в поетичній системі цุілісний образ автора додатковими, слабко виявленими в особі ліричного героя особистісними якостями. Обмеживши коло героїв, які називаються рольовими, місием побутування (а ц̧е - література $і$ фольклор), ми не згодні в розумінні рольової лірики... з деякими дослідниками, які поєднують ї̈ із віриами, написаними від імені персонажа» [8, с. 212].

В 60-70-ті роки XX ст. до проблеми рольової лірики зверталися О. Гаркаві, В. Скобєлєв, В. Богданов, І. Роднянська та ін., але найбільше уваги характеристиці іï теоретичного феномену в цей період приділив відомий російський дослідник Б. Корман, який досліджував іï переважно на матеріалі поезії М. Некрасова. Сутність рольової лірики Б. Корман визначав так: «Суmь «рольової» лірики полягає в тому, щуо автор в ній виступає не від свого обличчя, а від імені різних героїв. Тут використовується ліричний спосіб оволодіння епічним матеріалом: автор дає слово героям, суттєво відмінним від нього. Він присутній у вірші, але немовби розчинивщись у своїх героях, одягнувши їхню маску...» $[9$, с. 165]. 
Дещо по-іншому намагається інтерпретувати феномен рольової лірики О. Гаркаві. 3 одного боку, він поділяе погляди Б. Кормана, стверджуючи: «рольова лірика фактично перебуває на межі лірики та епосу. Мова йде про невеличкі вірші, яким надано форми стилізації: розповідь організовано не від особи автора, а від імені одного із персонажів», з іншого боку, простежується спроба диференціювати різні типи оповіді, написані «не від особи автора, а від особи одного із персонажів» [10, с. 55].

3 іншого боку, дослідник вважає, що до рольової лірики слід відносити лише вірші, «написані від імені позитивних персонажів». У віршах, «написаних від імені негативних персонажів, явно відсутнє «ліричне освоєння світу»; у них відсутній ліризм... ці «рольові» вірші наближені за формою до монологу водевільного шахрая або до сатирів, що побудовані посередництвом прийому «маски добропорядної людини» [10, с. 57].

В. Скобєлєв, коментуючи дискусію О. Гаркаві і Б. Кормана, наполягає на тому, що рольовий герой, зберігаючи свій, нетотожний авторському суб'єктний статус, водночас прагне до того, щоб розчинитися в авторській свідомості. На думку В. Скобєлєва, «суть проблеми полягає в тому, щоб, по-перше, визначити відстань між автором і носієм мови i, по-друге, встановити, яка тенденція переважає - взаємовідстояння автора і носія мови або, навпаки, взаємовплив» [11, c. 32].

Спосіб виокремлення із загального масиву поетичних творів текстів рольової лірики і метододологію їхнього аналізу вчений вбачає у вивченні суб’єктної організації кожного окремого вірша з точки зору того, який родовий тип суб'єктної організації переважає або вони діють, так би мовити, на рівних» [11, c. 34].

Серед дослідників рольової лірики немає одностайності не лише стосовно iii суб’єктної ідентичності, родової приналежності, типу використовуваного нею героя, але й термінології, що застосовується на означення іiі художнього феномену. 
Найбільш часто вживаним термінологічним синонімом рольової лірики у сучасному літературознавстві $є$ поняття «персонажна лірика». Семантика цього терміну, очевидно, має на увазі аналогію рольового героя лірики з персонажами епічних та драматургічних творів. Одним 3 перших цей термін запровадив Г. Поспєлов, за концепцією якого «персонажна» лірика охоплює поетичні твори, в яких «об’єктом ліричної медитації стає окрема особистість, яка втілює у собі характерність соціального буття, наділена певними індивідуальними рисами, а іноді і власним ім'ям, і тому може називатися «персонажною». Але, на відміну від епічних персонажів, ця особистість не постає у творі безпосередньо, у своїй часово-просторовій визначеності, і не формує своїми діями сюжет твору. Звідси сама форма іï зображення виявляється не розповідною, але по-своєму медитативно-описовою і при цьому - за загальним законом ліричних медитацій - відносно невеликою за своїм обсягом» $[12$, c. 150$]$.

Як синонім рольової лірики термін «персонажна лірика» використовує відомий український дослідник теоретичних проблем поезії М. Ткачук. «Рольову лірику називаємо «персонажною». - Пише М. Ткачук. - Борис Корман розрізняв носія свідомості й носія мовлення, адже часто в текстах не чітко окреслюються межі між кутами зору. Термін власне автор не чітко розмежовує ліричного суб'єкта 3 біографічним автором. Тому варто виділити автопсихологічну і рольову, персонажну лірику» [13, с. 284].

Термін «персонажна лірика» використовує й Н. Лівицька, яка визначає іiі як «своєрідну модифікацію поетичного жанру, у якій головним носієм авторської інтенції виступає ліричний персонаж («герой рольової лірики», за Корманом), світорозуміння і роздуми якого відмінні від внутрішнього світу автора. У межах художнього цілого функціонує не реальний поет, а виражена ним «подоба», що виявляється через «трансгресію «Іншого» (О. Ікомасова)» $[14$, c. 95$]$.

Спробу переосмислення та доповнення традиційної термінології робить Н. Загребельна, яка у дисертації «Ліричний суб’єкт поезії XX ст.: форми 
конституювання і репрезентації», окрім власної дефініції ліричного суб'єкта «як фігури, котра: 1) об’єднує експліцитного автора й персонажа, 2) перебуває між «автором» i «героєм», 3) корелює 3 автором i реципієнтом», вибудовує відповідну типологію: «неперсоніфікований, абстрагований, конкретизований, фіктивний (щуо не суперечить автопсихологічності) та дистаниійований» $[15$, c. 9$]$.

Феномен рольової лірики досліджують і представники західноєвропейського літературознавства. В німецькому літературознавстві поняття, аналогічне рольовій ліриці - Rollenlyric - використовується 3 першої половини ХX ст. [16].

В англійському літературознавстві термінологічним аналогом «рольової лірики» виступає поняття «драматичного діалогу» (dramatic monologue). Втім, це поняття не зовсім точно відображає семантичні ознаки рольової лірики i стосується не лише художніх явищ, у яких актуалізовано суб'єкта мовлення (speaker, persona), свідомість якого відмінна від авторської.

Отже, як можна зробити висновок, загальноприйнятої концепції рольової лірики у сучасному літературознавстві ще не розроблено, відповідно, іiі художній феномен не ідентифіковано у понятійному обсязі, який би чітко окреслював іï художню сутність та визначальні семантичні ознаки. Не уніфіковано й літературознавчу термінологію на позначення цього художнього явища. На нашу думку, із загального числа термінів, запропонованих сучасним літературознавством, найбільш вдалим $\epsilon$ саме термін «рольова лірика», що найбільш точно відображає семантичну сутність ії явища як лірики, у якій автор говорить не від себе, а від особи уявного суб'єкта мовлення, роль якого він у даному разі виконує (як, власне, і вигаданий ним суб'єкт мовлення виконує, хоча б і фіктивно, роль автора поетичного тексту). Найбільш близький i часто уживаний термінологічний аналог рольової лірики, а саме - лірика персонажна, на нашу думку, не зовсім чітко відображає основоположні семантичні ознаки іiі художнього феномену. Насамперед, змальований у 
поетичному творі персонаж далеко не завжди виступає суб’єктом мовлення (а лише об'єктом авторського зображення).

Висновки i перспективи подальших досліджень. Дослідження феномену рольової лірики засвідчує, що проблему встановлення чітких понятійних меж між окреслюваними в тих або тих типологічних моделях побудови суб’єктної сфери ліричного твору й на сьогоднішній день навряд чи можна вважати вирішеною остаточно. До числа гостродискусійних питань дослідження наголошеної у статті наукової проблематики, які потребують подальшого вивчення, відносяться проблеми означення художніх різновидів, а також класифікації типів героїв рольової лірики.

\section{Література}

1. Хализев В. Е. Теория литературы / В. Е. Хализев - Москва : «Высшая школа», 2002. - 437 с.

2. Орлова Е. И. Образ автора в литературном произведении / Е. И. Орлова. - Москва, 2008. - 256 с.

3. Васильев И. Е. Стихотворный сказ Vs Ролевая лирика : границы и возможности «неавторского» высказывания / И. Е. Васильев // Кормановские чтения : статьи и материалы Межвузовской научной конференции (Ижевск, апрель, 2013) / ред.-сост. Д. И. Черашняя. - Ижевск, 2013. - Вып. 12. - С. 58-63.

4. Анализ лирического стихотворения : учеб. пособие. / Е. А. Балашова, И. А. Каргашин. - М. : Флинта : Наука, 2011. - 192 с.

5. Андриенко Е. В. Коммуникативная типология поэтических текстов В. Высоцкого / Е. В. Андриенко // От словаря В. И. Даля к лексикографии XXI века : материалы междунар. симпозиума, посвящ. двухсотлетию В. И. Даля, 30 окт.-2 нояб. 2002 г. : научный сборник / ИРЯЛ ДВГУ. Владивосток : Изд-во ДВГУ, 2002. - С. 28-54.

6. Ревзина О. Г. Коммуникативная типология поэтических текстов / О. Г. Ревзина // Коммуникативная структура поэтического текста. - Ереван, 1990. - C. 112-116. 
7. Артемова С. Ю. Ролевая лирика / С. Ю. Артемова // Поэтика : Словарь актуальных терминов и понятий [гл. науч. ред. Н. Д. Тамарченко]. - Москва : Издательство Кулагиной ; Intrada, 2008. - 358 с.

8. Тилипина Т. П. О соотношении ролевого и лирического героев / Т. П. Тилипина // Мир Высоцкого : Исследования и материалы. / Сост. А. Е. Крылов и В. Ф. Щербакова. - М. : ГКЦМ В. С. Высоцкого, 1999. Вып. III. - T. 1. - С. 212-218.

9. Корман Б. О. Лирика Некрасова / Б. О. Корман. - Ижевск : «Удмуртия», 1978. $-300 \mathrm{c}$.

10. Гаркави А. М. Проблема родовой классификации литературных жанров и некоторые возможности изучения лирики Н. А. Некрасова / А. М. Гаркави // Жанр и композиция литературного произведения : межвузовский сборник. - Калининград, 1976. - Вып. 2. - С. 49-63.

11. Скобелев В. П. Системно-субъектный метод в трудах Б. О. Кормана / В. П. Скобелев. - Ижевск : Изд-во Удмуртский ун-т, 2003. - 153 с.

12. Поспелов Г. Н. Лирика среди литературных родов / Г. Н. Поспелов. М. : Издательство Московского университета, 1976. - 208 с.

13. Ткачук М. Українська література XX століття : монографія / М. Ткачук. - Тернопіль : Медобори, 2014. - 608 с.

14. Лівицька Н. Ліричний суб’єкт «персонажної» лірики для дітей Миколи Вінграновського / Н. Лівицька // Література. Діти. Час. Вісник центру дослідження літератури для дітей і юнацтва. Рівне : Дятлик, 2013. - Вип. 4. C. $95-102$.

15. Загребельна Н. Ліричний суб’єкт поезії XX століття : форми конституювання та репрезентації : автореф. дис. на здобуття наук. ступеня канд. філол. наук : спец. 10.01.06 - Теорія літератури / Н. Загребельна. - К., 2008. $-18 \mathrm{c}$.

16. Walzel O. Schicksale des lyrischen Ichs / O. Walzel. - Idem. Das Wortkunstwerk. Mittel Seiner Erforshung. Leipzig., 1926. 